\title{
PENGARUH MODEL PEMBELAJARAN KOOPERATIF GROUP INVESTIGATION TERHADAP HASIL BELAJAR SISWA PADA MATERI USAHA DAN ENERGI DI KELAS X SMA NEGERI 12 MEDAN
}

\author{
Dian Limbong ${ }^{1)}$, Rahmatsyah ${ }^{2)}$ \\ ${ }^{1,2)}$ Pendidikan Fisika Universitas Negeri Medan \\ e-mail: dian.limbong4@gmail.com \\ rahmatunimed@gmail.com
}

\begin{abstract}
Abstrak
Penelitian ini bertujuan untuk mengetahui hasil belajar siswa dan aktivitas belajar siswa dengan menggunakan model pembelajaran kooperatif tipe group investigation dan pembelajaran konvensional. Jenis penelitian adalah quasi eksperimen, dan pengambilan sampel dilakukan secara simple random sampling. Instrumen yang digunakan dalam penelitian ini yaitu tes hasil belajar kognitif. Dari analisa data untuk hasil belajar kelas eksperimen diperoleh rata-rata pretest 46,667 dan postes 73,714. Kelas kontrol diperoleh ratarata pretest 40,381 dan postes 60,761. Hasil analisis data menggunakan uji t satu pihak, dimana uji t diperoleh $t_{\text {hitung }}=4,056$ sedangkan $t_{\text {tabel }}=1,668$ karena $t_{\text {hitung }}>t_{\text {tabel }}$ maka ada perbedaan yang signifikan. Hal ini menunjukkan ada pengaruh penggunaan model pembelajaran kooperatif tipe group investigation terhadap hasil belajar siswa pada materi usaha dan energi di kelas X Semester II SMA Negeri 12 Medan T.P $2016 / 2017$
\end{abstract}

Kata kunci : aktivitas belajar, kooperatif tipe group investigation, hasil belajar

\begin{abstract}
The purpose of this research is to know the student learning outcomes and student learning activities that use Cooperative Type Group Investigation model and conventional learning. The type of research is quasi experiment, and the sampling is done by simple random sampling. The instrument used is the cognitive learning outcomes test. From the data analysis for the experimental class learning outcomes, it results in an average of pretest 46,667 and posttest 73,714. The control class results in an average of pretest 40,381 and posttest 60,761. The result of data analysis using t-one test, when the result of t test is $t_{\text {hitung }}=4,056$ while $t_{\text {tabel }}=1,668, t_{\text {hitung }}>t_{\text {tabel }}$. Because then there is a significant difference, this shows there is the influence of the use of cooperative learning model of type group investigation of toward student learning outcomes content Work and Energy in class X Semester II SMA Negeri 12 Medan T.P 2016/2017.
\end{abstract}

Keywords : learning activities, cooperative type group investigation, learning outcomes 


\section{Pendahuluan}

Pendidikan merupakan proses tingkah laku anak didik agar menjadi manusia dewasa yang mampu hidup mandiri dan sebagai anggota masyarakat dalam lingkungan alam sekitar dimana individu itu berada (Purba, 2015). Untuk mencapai pendidikan yang demikian maka dalam proses pembelajaran diperlukan kurikulum sebagai pedoman. Kurikulum yang saat ini dikembangkan dalam sistem pendidikan nasional adalah kurikulum 2013 (Hamalik, 2010). Salah satu masalah pokok dalam pembelajaran kurikulum 2013 pada pendidikan formal dewasa ini adalah masih rendahnya daya serap peserta didik.

Masalah ini menjadi faktor penghambat tercapainya tujuan pembelajaran yang diharapkan pada mata pembelajaran Fisika ditingkat SMA. Pemahaman yang benar akan pelajaran fisika akan sangat berpengaruh terhadap hasil belajar siswa. Akan tetapi, pada kenyataannya hasil belajar peserta didik pada pembelajaran fisika masih sangat rendah. Rendahnya hasil belajar fisika yang diperoleh oleh siswa salah satunya disebabkan model pembelajaran yang digunakan oleh guru kurang bervariasi (Suryadana et al., 2012 dalam Sofia, 2014). Selain itu, guru juga menggunakan metode ceramah, tanya jawab dan penugasan sehingga banyak siswa yang menyatakan bahwa pelajaran fisika itu merupakan pelajaran yang sulit untuk dipahami dan membosankan (Sofia, 2014).

Berdasarkan hasil wawancara yang dilakukan peneliti dengan salah satu guru fisika yang mengajar di SMA Negeri 12 Medan mengatakan bahwa hasil belajar fisika siswa juga masih rendah, hal ini telihat dari hasil ujian semester I tahun ajaran 2015/2016 siswa belum mencapai Kriteria Ketuntasan Minimal (KKM) atau masih di bawah 75 . Berdasarkan observasi yang dilakukan oleh peneliti di SMA Negeri 12 Medan dengan menyebarkan angket kepada 35 siswa kelas $\mathrm{X}$ saat observasi awal. Data yang diperoleh melalui angket menunjukkan bahwa siswa menyatakan pelajaran fisika mudah menyenangkan sebanyak 18,91\% (7 siswa), menyatakan sulit sebanyak 40,54\% (15 siswa), menyatakan biasa saja sebanyak 37,83\% (12 siswa) dan menyatakan membosankan sebanyak $2,70 \%$ (1 siswa). Saat diberikan pernyataan mengenai cara belajar yang dinginkan, sebanyak $29,72 \% \quad(11$ siswa $)$ menginginkan belajar fisika yang banyak praktek dan demonstrasi, 45,94\% (15 siswa) menginginkan bermain sambil belajar, dan $24,32 \%$ (9 siswa) menginginkan banyak mengerjakan soal.

Berdasarkan permasalahan tersebut, maka salah satu upaya yang dilakukan untuk mengatasi permasalahan tersebut adalah dengan pemilihan model pebelajaran yang tepat yaitu dengan mengembangkan model pembelajaran yang efektif, yang melibatkan siswa secara aktif, memperhatikan kemampuan siswa dan mempergunakan alat peraga yang benar dan dapat memperbaiki pemahaman siswa akan konsep-konsep fisika dengan melibatkan siswa secara aktif, sehingga siswa dapat belajar secara personal maupun kelompok dengan suasana menyenangkan. Salah satu alternatif yang dapat digunakan untuk mengatasi permasalahan ini adalah dengan menggunakan model pembelajaran kooperatif tipe Group Investigation (GI) (Eggen dan Kauchak, 1996 dalam Trianto, 2011).

Model pembelajaran kooperatif tipe Group Investigation merupakan perencanaan pengaturan kelas yang umum dimana para siswa bekerja dalam kelompok kecil menggunakan pertanyaan kooperatif, diskusi kelompok, serta perencanaan dan proyek kooperatif (Sharan dan Sharan, 1992 dalam Slavin, 2005). Model pembelajaran Group Investigation adalah salah satu bentuk model pembelajaran kooperatif yang memiliki titik tekan pada partisipasi dan aktivitas siswa untuk mencari sendiri materi atau segala sesuatu mengenai materi pelajaran yang akan dipelajari. Informasi tersebut dapat dilihat dari bahan-bahan yang tersedia, misalnya dari buku pelajaran, perpustakaan, atau bahan dari internet dengan referensi yang bisa dipercaya kebenarannya. Hal yang paling penting dari model ini adalah dapat melatih siswa untuk menumbuhkan kemampuan berpikir mandiri (Kurniasih, 2015).

Group Investigation merupakan salah satu model pembelajaran yang bersifat demokratif karena siswa menjadi aktif belajar dan melatih kemandirian dalam belajar. Dalam model ini, para siswa dibebaskan membentuk kelompoknya sendiri yang terdiri dari dua sampai enam orang anggota. Disamping itu 
siswa dituntut untuk belajar bekerja sama dengan anggota lain dalam satu kelompok. Siswa memiliki dua tanggung jawab yaitu, mereka belajar untuk dirinya sendiri dan membantu sesama anggota kelompok. Pada model pembelajaran ini, seorang siswa berinteraksi dengan siswa lain dalam kelompok tanpa memandang latar belakang. Model pembelajaran kooperatif tipe Group Investigation ini, juga melatih siswa untuk memiliki kemampuan yang baik dalam berkomunikasi dan mengemukakan pendapatnya.

\section{Bahan dan Metode}

Penelitian ini dilaksanakan di Kelas X Sma Negeri 12 Medan tahun akademik 2016/2017. Sampel dalam penelitian ini terdiri dari dua kelas yaitu kelas kontrol dan kelas eksperimen yang diambil dengan teknik simple random sampling. Kelas eksperimen diterapkan model pembelajaran kooperatif tipe Group Investigation dan kelas kontrol menggunakan pembelajaran konvensional.

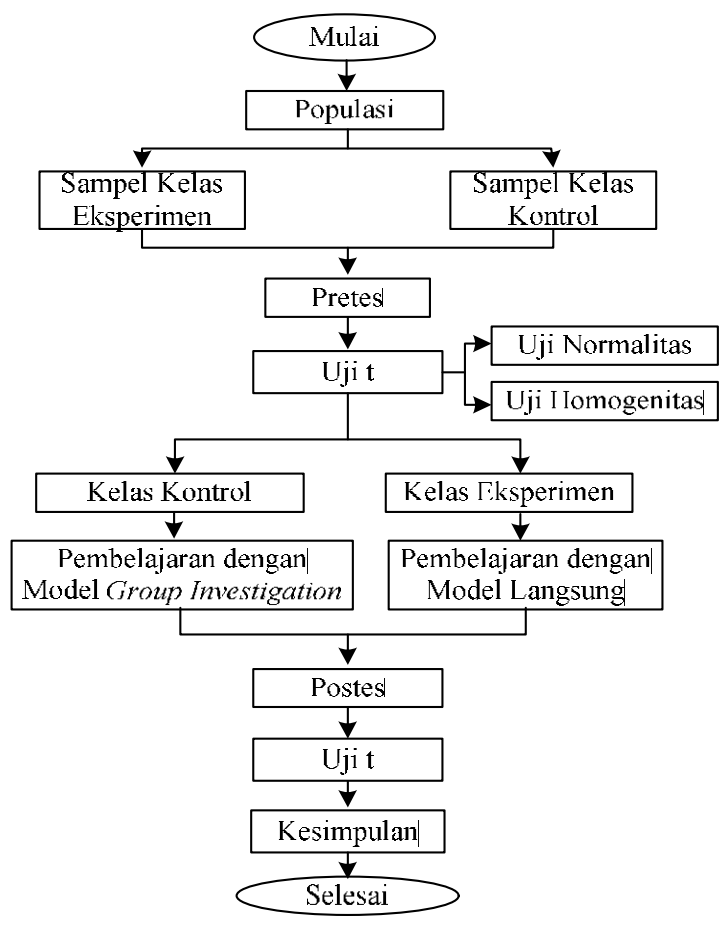

Gambar 1. Skema rancangan penelitian.
Tahapan dalam melaksanakan penelitian digambarkan dalam bentuk diagram alur seperti ditunjukkan pada Gambar 1.

Tes hasil belajar terlebih dahulu distandarisasi dengan menggunakan uji validasi isi oleh dua orang dosen pakar dibidangnya. Kemudian dari hasil pretes dan postes masing-masing instrumen yang diperoleh dilakukan uji normalitas, uji homogenitas, uji-t dua pihak dan uji-t satu pihak.

\section{Hasil dan Pembahasan}

Data dari hasil penelitian berupa hasil belajar kognitif siswa pada pretest dan postest masing-masing instrumen. Hasil pretes pada kelas eksperimen dan kelas kontrol dirangkumkan dalam bentuk distribusi frekuensi yang ditunjukkan pada Tabel 1 . Lebih jelasnya distribusi frekuensi data postes siswa kelas eksperimen dan kontrol dapat divisualisasikan pada Gambar 2.

Tabel 1. Hasil Pretes Kelas Eksperimen dan Kelas Kontrol

\begin{tabular}{|c|c|c|c|c|c|}
\hline \multirow[t]{2}{*}{ No } & \multirow{2}{*}{$\begin{array}{c}\text { Interval } \\
\text { Nilai }\end{array}$} & \multicolumn{2}{|c|}{$\begin{array}{c}\text { Kelas } \\
\text { Eksperimen }\end{array}$} & \multicolumn{2}{|c|}{$\begin{array}{c}\text { Kelas } \\
\text { Kontrol }\end{array}$} \\
\hline & & $f$ & $\bar{X} \boldsymbol{\&} \mathbf{S}$ & $f$ & $\bar{X} \boldsymbol{\&} \mathbf{S}$ \\
\hline 1 & $12-21$ & 0 & \multirow{6}{*}{$\begin{array}{l}\bar{X}=46,667 \\
S=12,100\end{array}$} & 6 & \multirow{7}{*}{$\begin{array}{l}\bar{X}=40,381 \\
\mathrm{~S}=15,920\end{array}$} \\
\hline 2 & $22-31$ & 3 & & 5 & \\
\hline 3 & $32-41$ & 12 & & 9 & \\
\hline 4 & $42-51$ & 6 & & 4 & \\
\hline 5 & $52-61$ & 10 & & 9 & \\
\hline 6 & $62-71$ & 4 & & 2 & \\
\hline \multicolumn{2}{|c|}{ Jumlah } & 35 & & 35 & \\
\hline
\end{tabular}

Perolehan nilai rata-rata pretest hasil belajar siswa di kelas eksperimen sebesar 46,667 dan nilai rata-rata pretes di kelas kontrol sebesar 40,381. Untuk melihat perbedaan kemampuan awal kedua kelas dilakukan uji hipotesis dengan uji prasyarat yaitu uji normalitas dan homogenitas. Hasil uji normalitas hasil belajar untuk kedua sampel diperoleh bahwa nilai pretes terdistribusi normal dimana ( $\mathrm{L}_{\text {hitung }}<\mathrm{L}_{\text {tabel }}$ ) dan berasal dari populasi yang homogen $\left(\mathrm{F}_{\text {hitung }}<\mathrm{F}_{\text {tabel }}\right)$. 


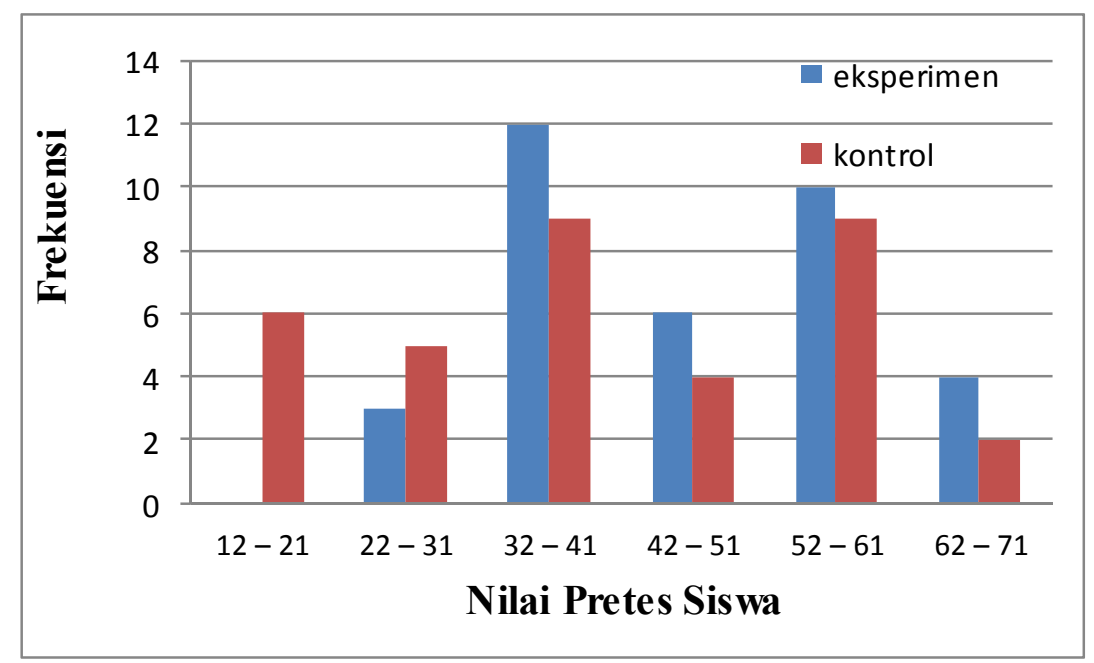

Gambar 2. Diagram nilai pretes kelas eksperimen dan kelas kontrol.

Hasil uji hipotesis pretes hasil belajar menggunakan uji t pada taraf signifikan $\alpha=$ 0,05 diperoleh $t_{\text {hitung }}<t_{\text {tabel }}(1,731<1,764)$, hal ini menunjukkan kemampuan awal kedua kelas sama.

Tabel 2. Hasil postes kelas eksperimen dan kelas kontrol

\begin{tabular}{cccc|cc}
\hline & \multirow{2}{*}{$\begin{array}{c}\text { Interval } \\
\text { Nilai }\end{array}$} & \multicolumn{2}{c|}{$\begin{array}{c}\text { Kelas } \\
\text { Eksperimen }\end{array}$} & \multicolumn{2}{c}{$\begin{array}{c}\text { Kelas } \\
\text { Kontrol }\end{array}$} \\
\cline { 3 - 6 } & & $\boldsymbol{f}$ & $\bar{X} \boldsymbol{\&} \mathbf{S}$ & $\boldsymbol{f}$ & $\bar{X} \boldsymbol{\&} \mathbf{S}$ \\
\hline 1 & $33-43$ & 0 & & 6 & \\
2 & $44-54$ & 2 & & 8 & \\
3 & $55-65$ & 5 & $\bar{X}=73,714$ & 5 & $\bar{X}=60,761$ \\
4 & $66-75$ & 13 & 10 & $\mathrm{~S}=14,887$ \\
5 & $76-86$ & 7 & $\mathrm{~S}=11,765$ & 6 & $\mathrm{~S}$ \\
6 & $87-97$ & 8 & & 0 & \\
\multicolumn{2}{c}{ Jumlah } & 35 & & 35 & \\
\hline
\end{tabular}

Hasil postes pada kelas eksperimen dan kelas kontrol dirangkumkan dalam bentuk distribusi frekuensi pada Tabel 2. Lebih jelasnya distribusi frekuensi data postes siswa kelas eksperimen dan kontrol dapat divisualisasikan pada Gambar 3.

Perolehan nilai rata-rata postes hasil belajar siswa di kelas eksperimen sebesar 73,714 sedangkan nilai rata-rata postes di kelas kontrol sebesar 60,761. Hasil uji normalitas hasil belajar untuk kedua sampel diperoleh bahwa nilai pre-test berdistribusi normal dimana $\left(\mathrm{L}_{\text {hitung }}<\mathrm{L}_{\text {tabel }}\right)$ dan berasal dari populasi yang homogen $\left(\mathrm{F}_{\text {hitung }}<\mathrm{F}_{\text {tabel }}\right)$.

Hasil uji hipotesis postes hasil belajar menggunakan uji t pada taraf signifikan $\alpha=$
0,05 diperoleh $t_{\text {hitung }}>t_{\text {tabel }}(4,056>1,668)$, hal ini menunjukkan bahwa ada perbedaan hasil belajar siswa menggunakan model pembelajaran kooperatif tipe group investigation dengan model pembelajaran konvensional.

Hasil penelitian ini menyatakan hasil belajar fisika dengan menggunakan model pembelajaran kooperatif tipe group investigation lebih tinggi daripada model pembelajaran konvensional. Hal ini sejalan dengan penelitian terdahulu seperti yang diteliti oleh Lumbatorua dengan judul "Pengaruh Model Pembelajaran Kooperatif Tipe Group Investigation (GI) Untuk Meningkatkan Hasil Belajar Siswa Pada Materi Pokok Suhu dan Kalor". Dalam penelitian ini Lumbatorua mengemukakan bahwa ada pengaruh penggunaan model pembelajaran Group Investigation terhadap hasil belajar. Nilai rata-rata pretes pada kelas eksperimen 37,13 dan nilai rata-rata pada kelas kontrol 26,75. Peneliti memberikan perlakuan yang berbeda, nilai rata-rata postes pada kelas eksperimen dengan perlakuan model pembelajaran Group Investigation adalah 70,75 sedangkan pada kelas kontrol dengan model pembelajaran konvensional nilai ratarata postes adalah 54,88 . Hal ini berarti hasil belajar siswa pada kelas eksperimen meningkat sebesar 33,62 dan kelas kontrol 18,13 (Lumbantorua,2016).

Hasil penelitian ini menyatakan bahwa hasil belajar fisika dengan menggunakan model pembelajaran kooperatif tipe group 
investigation lebih tinggi daripada model pembelajaran konvensional. Sedangkan hasil perkembangan aktivitas belajar siswa yang diperoleh dari kelas eksperimen dapat dilihat pada Gambar 3.

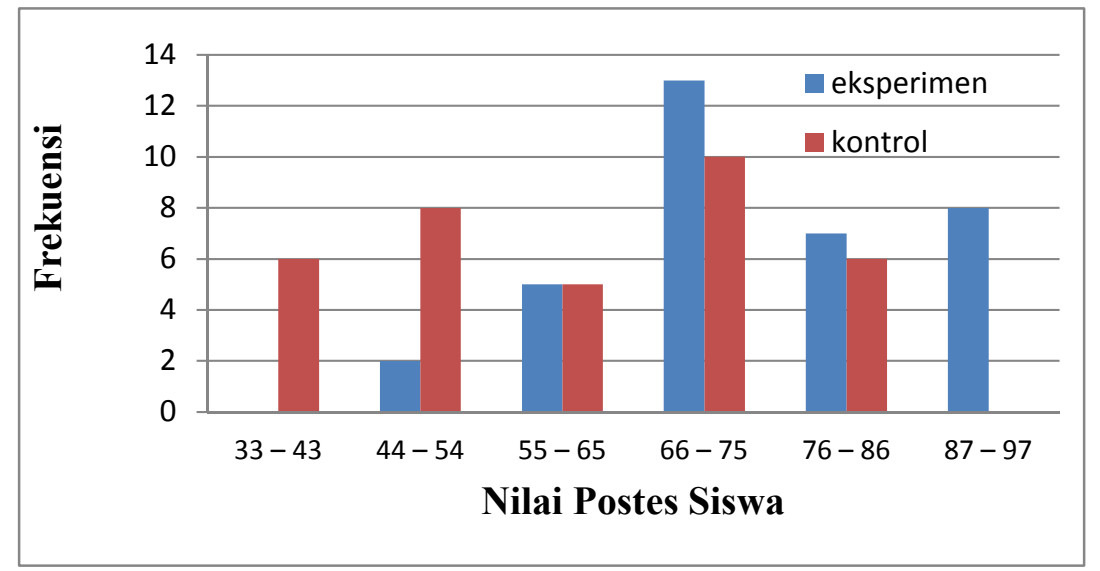

Gambar 3. Diagram nilai postes kelas eksperimen dan kelas kontrol.

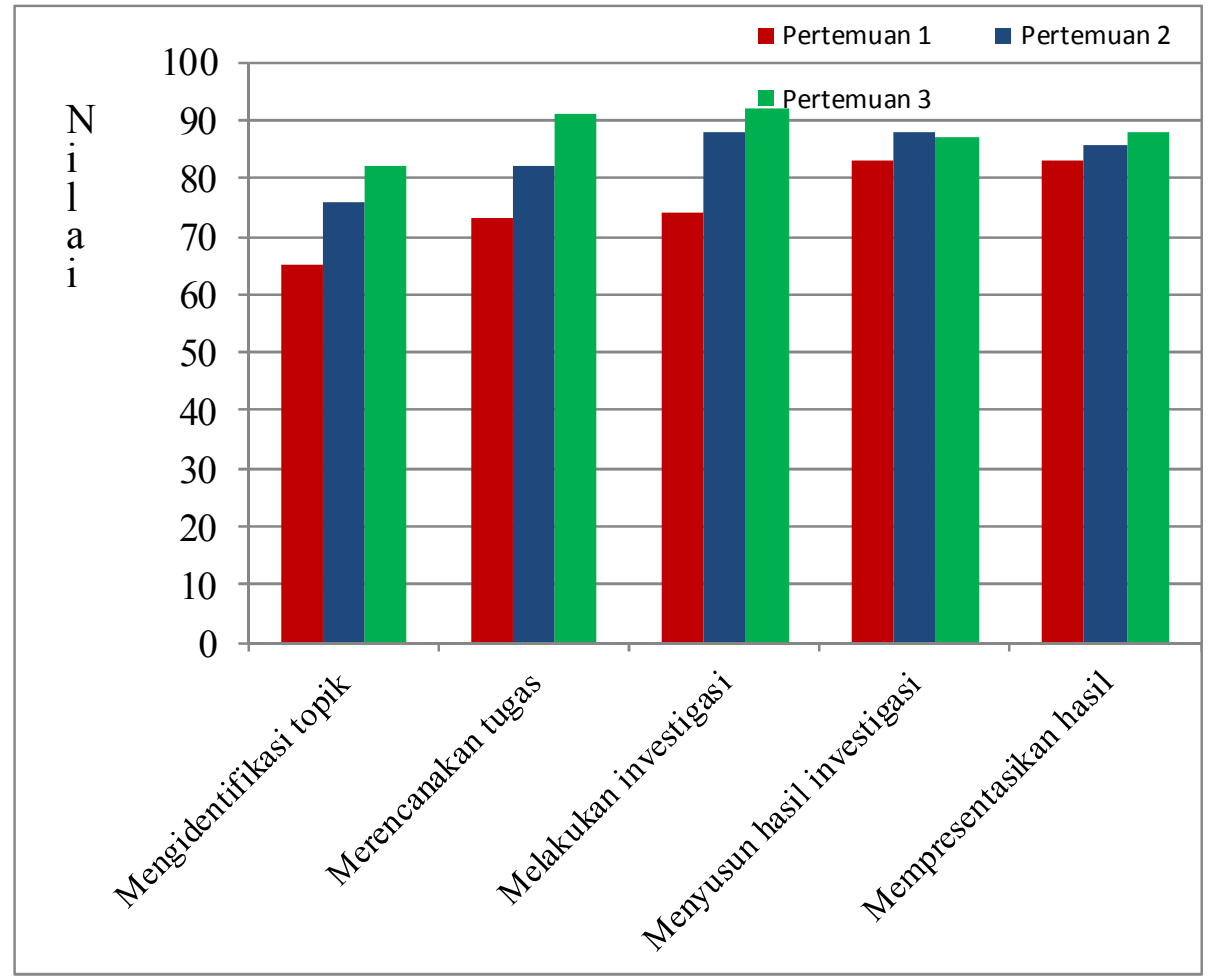

Gambar 4. Diagram perkembangan aktivitas siswa kelas eksperimen. 
Gambar 4 menunjukkan bahwa perkembangan aktivitas belajar siswa di kelas eksperimen mengalami peningkatan untuk setiap aspeknya. Hal ini berarti pembelajaran dengan model pembelajaran kooperatif tipe group investigation dapat meningkatkan aktivitas belajar siswa, karena dengan model pembelajaran investigation siswa dilibatkan secara penuh dalam kegiatan belajar untuk memperoleh informasi dan pengetahuan.

Group Investigasi membantu siswa untuk melakukan investigasi terhadap suatu topik secara sistematis dan analitik. Hal ini berhubungan dengan hasil belajar siswa uang meningkat berhubungan dengan tujuan dari model pembelajaran kooperatif tipe Group Investigation yaitu siswa dapat melakukan investigasi terhadap suatu topik secara sistematis dan analitik, pemahaman secara mendalam terhadap suatu topik yang dilakukan melalui investigasi, melatih siswa untuk bekerja secara kooperatif dalam memecahkan suatu masalah, dan mempunyai implikasi yang positif terhadap pengembangan keterampilan penemuan serta membantu mencapai tujuan pembelajaran.

\section{Kesimpulan dan Saran}

Kesimpulan yang diperoleh yaitu, terdapat pengaruh model pembelajaran kooperatif tipe Group Investigation terhadap hasil belajar siswa pada materi pokok usaha dan energi di SMA Negeri 12 Medan, serta didukung oleh adanya aktivitas belajar siswa yang meningkat.

Sebagai tindak lanjut dari penelitian ini disarankan dalam pembagian kelompok harus lebih dimaksimalkan dengan cara menyeleksi siswa berdasarkan nilai pretes atau direkomendasikan oleh guru mata pelajaran terkait.

\section{Daftar Pustaka}

Hamalik, O., 2010. Kurikulum dan Pembelajaran. Bumi Aksara, Jakarta.

Kurniasih, I dan Berlin S., 2015. Ragam Pengembangan Model Pembelajaran Untuk Peningkatan Profesionalitas Guru. Kata Pena, Jakarta.

Lumbantorua, D dan Makmur, S., 2016. Pengaruh Model Pembelajaran Kooperatif Tipe Group Investigation (GI) Untuk Meningkatkan Hasil Belajar Siswa Pada Materi Pokok Suhu Dan Kalor. Jurnal Inpafi, 4 (4), 15-22.

Purba, E., \& Yusnadi., 2015. Filsafat Pendidikan. Unimed Press, Medan.

Sakinah, F., \& Purwanto, 2014. Pengaruh Model Pembelajaran Kooperatif Tipe Group Investigation Terhadap Hasil Belajar Siswa Pada Materi Pokok Suhu dan Kalor Kelas X SMA Negeri I Perbaungan. Jurnal Inpafi, 2 (3), 84-88.

Sitinjak, J.F.D., \& Sahyar, 2015. The Effect Of Cooperative Learning Model Type Group Investigation (GI) to Students' Learning Outcome On Linear Motion Topic. Jurnal Inpafi, 3 (2), 60-66.

Slavin, R.E., 2005. Cooperative Learning. Nusa Media, Bandung.

Sofia, M., \& Mariati, 2014. Pengaruh Model Pembelajaran Kooperatif Tipe Group Investigation (GI) Berbantuan Media Komputer Terhadap Hasil Belajar Siswa Pada Materi Pokok Listrik Dinamis di Kelas X Semester II SMA Negeri 10 Medan T.A 2013/2014. Jurnal Inpafi, 2 (4), 97-104.

Sudjana, 2009. Metoda Statistika. Tarsito, Bandung.

Trianto, 2011. Mendesain Model Pembelajaran Inovatif-Progresif. Kencana Prenada Media Group, Jakarta. 